\title{
ARTISTIC CHALLENGES OF ALESSANDRO BARICCO - LITERATURE AND MUSIC
}

\author{
UDC $(78+82): 792$ Barik, A
}

\section{Ljiljana Petrović}

\author{
University of Niš, Faculty of Arts, Serbia
}

\begin{abstract}
The theme of the paper is the multidisciplinary activities of the Italian writer Alessandro Baricco. Blending elements of literature and music Baricco is a music critic and creator of a television series that promotes not only opera, but also many hybrid art forms. They unite literature and music as well as special theater performances - Totem, public readings, rave readings, literature playlists. In these activities, the writer's postmodern orientation and tendency towards performance are recognizable. The paper also points to the frequent discrepancies between the critics and the audience when it comes to the reception of his works, as well as the polarization of the critics themselves.
\end{abstract}

Key words: literature, music, reading, opera, theater

\section{INTRODUCTION}

Alessandro Baricco was born in Turin in 1958 and is one of the most famous and most versatile contemporary Italian writers. His works have been translated into almost all world languages, and he won prestigious literary awards. ${ }^{1}$ From the moment of his debut on the Italian literary scene, Baricco has not ceased to be in the focus of public attention. Open minded and with a wide range of interests, productive in everything he does, full of innovative ideas and capable of putting these ideas into action, Baricco has been on this scene continuously for almost four decades as a novelist, drama writer, music and literary critic, TV presenter, director, stage designer, actor, and manager of various innovative art projects. Nevertheless, in this wide spectrum, there are two main poles around which his entire creation is organized: literature and music.

Received March 2019 / Accepted April 2019

Corresponding author: Ljiljana Petrović

University of Niš, Faculty of Arts

E-mail: ljiljanalingua@gmail.com

${ }^{1}$ The Viareggio Prize for the novel Ocean Sea(Oceano Mare), the Médicis etranger Prize for the novel Lands of glass (Castelli di Rabbia), the Giovanni Boccaccio Prize for the Emaus (Emmaus) novel, the FriulAdriaPrize for the novel This Story(Questa storia), the Cesare Pavese Prize for novel Three times at dawn (Tre volte all'alba). 
His literary beginnings are related specifically to music topics. First, in 1988, he published an essay dedicated to Rossini and his work, The Runaway Genius (Il genio in fuga), and then in 1992, the essay Hegel's Soul and the Cows from Wisconsin (L'anima di Hegel e le mucche del Wisconsin).Both of them deal with the relationship between classical music and modern times.

Many characters related to music by their fate, professionals or just passionate lovers, trooped through his literary work. Two of them are fully dedicated to musicians: Spanish Party (Partita spagnola) and Novecento. The Spanish Party tells the story of Farinelli, a famous $18^{\text {th }}$ century castrato singer, while Novecento is a saga about the fate of an anonymous pianist of marvelous talent who never left the overseas ship where he was born. Novecento was published in the form of a theater monologue in 1994, and four years later it was staged for the first time by Gabriele Vacis. Baricco wrote Spanish party with Lucia Moisio (Lucia Moisio) as a set design for a film that has never been produced. The work was published in 2003. Although the characters of these works are placed in different cultural contexts and different periods of time, it seems that they are only different embodiments of the same psychological profile, which Baricco himself observes in the post scriptum of the Spanish Party. ${ }^{2}$

In addition to dealing with topics related to music in his literary works, Baricco has been publishing music criticism in La Repubblica and La Stampa for many years. He begins cooperation with these journals, as a music critic and editor of the cultural section immediately after completing his studies, and, with ups and downs it lasts until today.

\section{POPUlarization OF OPERA. PROMOTING OPERA}

The third but not the less important aspect of Baricco`s relation to classical music is about promoting it. With this aim in view, in 1993, he launched a series called "Love Is an Arrow" (L'amore è un dardo) ${ }^{3}$ on the third programme of the Italian state-run television RAI 3. The concept of the series was such that each of the shows was dedicated to one of the topics dealt with in operas: falling in love, fate, revenge, the topic of return home, jealousy, divorce, enthusiasm, long distance love ${ }^{4}$, and the whole show was dedicated only to an opera, for example, Bellini`s Norma or Puccini `s Turandot.

In the series Baricco deals with the most famous opera arias, analyzes the libretto and the musical structure of the piece, supporting his analysis with interesting facts and anecdotes related to their creation and performance. The author's interpretations interchange with the recordings of performances, rehearsals, interviews carried out in the most famous Italian opera houses, and it is oftentimes spiced by reading thematically

\footnotetext{
2 "If you think it well, the heart of the story is the same: there is someone who has got a divine gift to do something and, paradoxically, does it in secrecy, under protective and limited circumstances. And they do it for an unreasonable number of years, almost like a compulsive action which that failed to get rid of. And then, what a coincidence, in both stories the main character is a musician: the most prominent opera singer, the most famous pianist. The circumstances are completely different (a $18^{\text {th }}$ century court in the Farinelli case, an overseas ship from the 1920`s in the Pianist case): but that's the essence" (Bariko, Moisio 2007, 131).

3 The name itself is derived from one of today's replica in the Turandot operations "Ah! l'amore, l'amore ond'ardo" (love that flashes me).

${ }^{4}$ The theme is long distance love through the opera Lucia de Lammermoor, the theme of the serie - Traviata, Nabucco, jealousy - Otello, Rigoletto, the theme of the melancholy - Cavalleria Rusticana (Cavalleria rusticana), Boemi (La Bohème)...
} 
related literature and philosophical texts. Baricco explains that with this series he wanted to help his compatriots to get to know the opera they like so much, but, however, do not understand it well enough:

Opera is in our blood, we sing it, we listen to it: but, if we pay better attention, we do not know it. "Love Is an Arrow" is an attempt to shift the boundaries of such half understanding, and it does so in two ways. The first is simple: retelling the stories of the operas, for these are wonderful stories and people do not know them; also they convey a certain view of the world that is not as dumb as it seems to be. Besides, listening is a pleasure, and so is telling stories. Another way is to propose some parts from the operatic repertoire, revealing in a simple way their drama function, sometimes their musical profile, often the feelings, fears and wishes they convey ${ }^{5}$ (Archivio. AdnAgenzia 1995).

The series was a huge success and nowadays it is often called a cult series in the Italian press.

\section{LITERATURE AS JAZZ - TOTEM}

After the "Love Is an Arrow" series, Baricco decides to put on the stage something of a completely new genre, and this is how the piece Totem is created. Reading, Sounds, Lectures (Totem. Letture, suoni, lezioni), premiered in 1997, and after that it was performed with a great success throughout Italy, until August 2001 (on several occasions a television broadcast was also organized).

Totem represents the kind of a musical-stage piece that Baricco calls "the non-theatrical performance happening in theater", which should be more than lectures, and less than a theater performance. The idea for such a project was born to Baricco and Vacis while they were giving lectures at the Baricco School of Creative Writing - Holden, in Turin. They wanted to reach their wider audience with their story of "cultural totems", that is, works of art from different epochs and civilizations. ${ }^{6}$ Baricco wrote plays, and Gabriele Vacis directed them. The third author of Totem, Roberto Tarasco, dealt with the tone and the light, and, unlike the previous two, did not appear on the stage.

The scene where the performance/non-performance was played was half-empty, only a few chairs, a score stand, a microphone, a piano, and the photographs related to the subject of the discussion. Baricco and Vacis read and commented on works of art, mostly in the field of literature and music, while other protagonists, if any, interchanged. They talked about Rilke, Rossini, Dickens, Aeschylus, Hemingway, Joyce, listening to Mozart, and La Traviata ...

The standard theater performance is replaced by a whole series of stage events: reciting poetry, listening to and performing music, screening of film scenes, reading

\footnotetext{
5 "L'opera la si ha nel sangue - ha dichiarato Baricco - la si canta, la si orecchia: ma poi, a ben vedere, non la si conosce. 'L'amore è un dardo!' cerca di allargare i margini di questa semi-ignoranza. Lo fa in due modi. Il primo è semplice: raccontare le storie delle opere. Perchè sono storie bellissime, perchèla gente non le conosce, perchè tramandano una certa visione del mondo che non è poi così stupida come sembra. E poi ascoltarle è un piacere. E raccontarle anche. Secondo sistema: proporre alcune pagine del repertorio operistico svelando in modo semplice la loro funzione drammatica, alle volte il loro profilo musicale, spesso i sentimenti, le paure e i desideri che tramandano" (Archivio.AdnAgenzia 1995).

${ }^{6}$ The name was given by a never accomplished television show that was supposed to deal with the masterpieces of classical music, but the name was accepted by Baricco and Vacis and assigned to him the meaning of a specific way of telling about culture.
} 
excerpts from books. The themes differed from performance to performance. They were often decided upon on the day before their performance. The performance of Totem was reduced to a good deal to improvisation and according to this criterion it should have been similar to playing jazz. That is why two Totem plays were never the same, they only had the same structure. The scheme of the pieces was established, but not the script, often the performance was spontaneously created while performing.

Totem, actually means that there are two presentations which are not performed on the same day, with the second being the continuation of the first. However, it turned out that such an organization could present a problem because it happens very often that the same audience is not present for both performances. The performances lasted for two to three hours, and the aim was to arouse emotions in the audience, to amaze them:

Totem is when you take something that is still able to amaze you: music, a page of a book, a theater play, a song (...) You take it to the theater, so that the world stays outside, while inside there remains silence for listening. Then you fill the theater with young people who still want to be amazed. And you give them that music, that book, that theater piece, that song. But taking away from them the intellectual and educational deposits that they have carried inside themselves for years. And from time to time, you try to explain how this thing is so beautiful, and why it still fascinates you today, although it was created over centuries ago, perhaps in a distant country, although it was created by people we even do not know who they $\operatorname{are}^{7}$ (Archivio> la Repubblica.it 1998).

Totem performances are organized seven to eight times a year. More frequent performance would question the originality of the author and thus jeopardize one of its basic postulates - the complete authenticity of each performance, from the choice of topic to the mode of performance and the means in use. If they were to get into the routine, the authors would not be amazed themselves in the first place, so they would not be able to amaze the audience and the goal of the performance would be completely missed. In December 1998, a two-part Totem performance was featured on national RAI2 television.

In 1999, a book about this show was published, and a year later two video tapes under the common name Totem. Reading, Sounds, Lectures. Later, in 2003, Baricco, Tarasco and Vacis returned to their project once again and published the book Whales and Dreams (Balene e Sogni) in which they talk about their experiences with this show, while Lucia Moisio directed a movie called Totem. The Last Tour (Totem. L`ultima tournée). Lucia Moiso followed the team that worked on Totem and recorded them in five cities during their tour. That is how the Totem movie came out, The Last Tour. ${ }^{8}$

\footnotetext{
7 "Totem vuol dire prendere qualcosa che ancora è in grado di maravigliarti: una musica, la pagina di un libro, un pezzo di teatro, una canzone...", spiega Baricco. "Porti questa cosa in teatro, così che il mondo rimane fuori, e lì dentro c'è il silenzio giusto per sentire. Poi riempi il teatro di gente giovane, che ha ancora voglia di meravigliarsi. E daì loro quella musica, quel libro, quel pezzo di teatro, quella certa canzone. Ma togliendogli di dosso tutta la muffa scolastica o intellettuale che si è portata dietro lungo gli anni. E ogni tanto cerchi di spiegare come mai quella cosa è così bella, e perchè riesce a stupirti ancora oggi, e magari l'hanno fatta secoli fa, o è stata creata in un paese che non c'entra niente, o da gente che non sappiamo chi è" (Archivio>la Repubblica.it 1998).

8 "The film is the synthesis of many hours of recording with the latest technology, and it returns us the" final" Totem, which authors consider to be the most mature and most exciting, and which has been taking place in recent years on stages throughout Italy from theaters to arenaa and cultural centers" (Baricco, Tarasco, Vacis 2003).
} 


\section{THE SOUND AND THE MUSIC OF WORDS - READING}

Encouraged by the success of the Totem performance Baricco wanted to repeat something similar, only this time the focus would no longer be on an opera, but exclusively on a text for reading. This is how another experimental form is created reading. At the Romaeuropa festival in 2002, two Baricco`s reading performances were premiered: City Reading Project, based on the excerpts from his novels City and Reading dell Iliade. The Citi Reading Project performance was a great success. A disk with the same name was recorded. It is a record of Baricco reading excerpts from his novel with the background music of the French group Air. A book with the same title was published. As for Homer's Iliad, the original text had to undergo significant changes in order to be more modern and closer to a contemporary reader - listener, the versification and the external objective narrator are omitted, so that the event is retold through 21 monologues of the participants/witnesses of the Trojan War. The performance was even more successful than the first. Baricco read his work three nights in a row, a total of 12 hours, in front of 6600 listeners. ${ }^{9}$

Next year, the printed version of the performance Reading del'Iliade followed, under the title Homer, Iliad (Omero, Iliade), and two other public readings of integral texts in Rome and Turin followed as well. A significant value of this project is the fact that despite the changes of the text that Baricco had to perform he managed to reach the soul of Homer's poem, and to look upon "an archaic soul" through the "problematic human component", everything in the shape in which the antique epic poem was originally communicated - the oral mode.

Baricco would constantly return to the practice of public reading, claiming that this is the way the audience would return to the "heart of the novel", which is why the journalists called him a pioneer of the genre of "author reading" (Larcan 2007). So in 2005, at the Paladium Theater in Rome, he read Fenoglio, Marquez and Carver. In 2007, in the same theater and in the same project, four artists: Alessandro Baricco, Paolo Rossi, Stefano Benni and Clive Russell read four excerpts of Moby Dick, Herman Melville`s novel. Six years later, in 2013, Baricco spoke in the same theater four nights, first of all about the English model Kate Moss who, according to him, is a symbol of the transition to mass aesthetics, then about Proust, Thucydides and Louis XVI. This was not a classic reading because Baricco did not only read excerpts from literary works, but also other types of texts, and in doing so relied strongly on his own interpretations and comments. These four theater evenings were later recorded on two DVDs, and a cover book was also issued.

\footnotetext{
9 "Last year, three nights in a row at the Romeeuropa Festival in Rome, there was an unusual happenning organized. One of the most important contemporary Italian writers, Alessandro Baricco, held a public reading of Homer's Iliade. The reading, which lasted twelve hours during three evenings, was followed by 6600 listeners, and was rated as a first-class cultural event. In order to bring Homer`s epic poem closer to the ear and attention of the modern listener, Baricco made some changes to the fabric of Iliade - he dropped out versification, and instead of an external narrator about events under Troy it is monologically testified by twenty-one participants and witnesses of the Trojan War, from Hriseide to Demodocus" (Ottolina 2003).
} 


\section{Literature RaVe, Literature Playlist and ViRtual PerformanCes}

Baricco and Francesco Bianconi, the leader of the indie rock group Baustelle, held on May 17, 2017, in the abandoned hall of Fiat's factory on the outskirts of Turin, the first literary rehearsal. Baricco read and commented on excerpts from Steinbeck`s novel Fruits of Fury, while Bianconi was in charge of musical accompaniment. It was a reading by the rules of the rave party - without seats, the audience stood in a huge hall. The reading was followed by live music, disks, vinyl sound carriers as well as synthesizers and sound modulators and a drum machine were also used. The same performance was repeated at the book fair in Turin, only on that occasion the audience was allowed to sit. One of Baricco`s literary raves was directly transmitted by the Italian national television RAI 3 (Mentelocaletorino 2017).

In 2018 Baricco enters a new literary-music project with Alessio Bertallot PLAYnovecento, which represents another rendition of the Novecento monologue. PLAYnovecento is neither an audiobook, nor a radio, or a playlist, but some kind of a dialogue between music and literature. The sections that Baricco reads interchange with the musical pieces selected by DJ A. B. This new version of Novecento is presented via the website and social networks - personal profiles of the authors. This is not the first time that Baricco organizes a promotion of some of his works over the Internet. His novels City (City) and Without Blood (Senza sangue) were presented to the public in the same way. In the first case, a special website was opened, and sometime later a forum of readers of the novel - City forum was formed. A year later, on this site, a three-hour chat with the author was organized, called A Direct Line with Alessandro Baricco. La Repubblica noted that the interest was such that the site had to be blocked as overloaded. The promotion of his second novel Without Blood was organized in the same way and had the same success. The whole approach was a novelty at its time $(1999-2000) .{ }^{10}$

Altogether with the project PLAYnovecento Baricco organizes a POP project (Palladio Olimpico Project) a virtual performance / a theater tour of the Olimpico Theater in Vicenza, the first covered theater in the world. The performance is devised so that the theater space becomes part of the narration, as well as its prologue and epilogue. At the entrance, visitors would get a tablet that would lead them through the most hidden parts of the old theater following Baricco. Baricco`s contact with the audience is also virtual through the big screen in the central hall. Before the virtual tour, the audience would be shown a sound and light game (Città di Vicenza 2018).

\section{AUDIENCE AND CRITICS}

Alessandro Baricco is definitely one of the most famous contemporary Italian writers. Though relatively young and at the peak of his creative power, his work has so far served as an inspiration to many artists. According to the monologue of the Novecento, another film The Legend of 1900 (La leggenda del pianista sulloceano) was made and directed by Giuseppe Tornatore as well as a comic strip The True Story of Novecento/La storia

\footnotetext{
10 "The most innovative experiment so far in Italy is that of Alessandro Baricco, who had his latest novel City presented exclusively on the Internet, via a three languages site opened for that particular purpose. The audience response was, on that occasion, great. So great that on June 29there were recorded 40.000 contacts on the site in the chatroom with the author. In three hours, as long as Baricco was connected, there was a shower of questions as much as 1300" (Ottolina, Carlini 2000).
} 
vera di Novecento. A Canadian director François Girard filmed in 2007 Baricco`s novel Silk, while the actress Angelina Jolie, in 2017, purchased the rights to screen the novel Without Blood. The same novel was turned into an opera in 2016; libretto was made by Mari Mezei, and the music composed by a Hungarian composer Peter Eotvos.

Still, regardless of the success and reputation that he enjoys among the readers` audience and art circles, literary critics around Baricco have been jousting from the moment he entered the literary scene to date. What is common to all of them is the glow and enthusiasm with which they speak about the writer, whether they are defending or attacking $\operatorname{him}^{11}$ :

Baricco is usually either loved or hated, there is no middle road: there are those who adore him and those who despise him, those who regard him as a deity of literature and those who place him in the worthless goods of postmodern pseudo-literature that is worth nothing (Pivano 2008).

Baricco is particularly unpopular among academic critics. In this context, one must especially mention his controversy with Giulio Ferroni and Pietro Citati (di Bari 2008, 10). He is resented mainly for superficiality and exhibitionism, and his success is justified by his playing up to the taste of the audience and by imposing himself onto a wide audience with a constant presence on radio and television. ${ }^{12}$ On the other hand, those who value and respect him go so far as to claim that Baricco is so revolutionary that literature after him will never again be the same:

Baricco (...) brings the idea that literature should be something violent, irresistible, magic, stuff woven from sleep, the same way Flaubert, Salinger, Gadda, Dickens were able to do it (...) and yet new, never created before (...) After such a novel (Lands of Glass), nothing more in literature will be able to be as before. ${ }^{13}$ (Pivano 2008)

Trying to evade the current criticism and polemics, the Italian writer Fernanda Pivano begins a review of the novel Lands of Glass (Castelli di rabbia) with the following words:

"Once when somebody writes a history of Italian literature at the end of the century, and when, as always, the time passes, the polemics mute, the bitterness and pettiness fade away, when we are forgiven lack of modesty, and the envy writers are prone to disappears, someone should have noticed that the Turinian Alessandro Baricco broke through the stale sky of the Italian culture of the last decade of the 20th century as a thunderbolt (...)" 14 (Pivano 2008).

\footnotetext{
${ }^{11}$ „Di solito Baricco lo si ama o lo si odia, non ci sono vie di mezzo: c’è chi stravede per la sua letteratura e chi la disprezza, chi lo ritiene un divo delle lettere e chi lo relega nella paccottiglia della pseudoletteratura postmoderna fatta di niente" (Pivano 2008).

${ }^{12}$ In these critical analyses, the problem of the aesthetic value of television as a mass medium remains open. As pointed out by Stojanovic Prelivic $(2018,83)$, "[t]he impact that television has on the audience is probably the main reason why many theorists are interested in media aesthetics."

13 „Baricco (...) comunica l'idea che la letteratura dovrebbe essere qualcosa di travolgente e appassionante, un incanto, una materia da sogno come sapevano lavorarla Flaubert, Salinger, Gadda, Dickens (...) e tuttavia nuova, mai fatta prima (...) Dopo un romanzo come questo, nulla, in letteratura, potrà più essere come prima" (Pivano 2008).

14 „Quando un giorno qualcuno scriverà una storia della letteratura italiana di fine secolo, e come sempre accade con il passare del tempo saranno sopite le polemiche, estinte le piccinerie e le acrimonie, perdonate le immodestie, svaporate le invidie che si agitano nel mondo delle lettere, quel qualcuno dovrebbe accorgersi che il torinese Alessandro Baricco ha squarciato come un fulmine il cielo stantio della cultura italiana dell'ultimo decennio del ‘900 (...)”(Pivano 2008).
} 


\section{CONCLUSION}

Experimental forms of performance that break down the barriers between literature and music represent a significant item in Baricco`s artistic opus. Although primarily a writer, it seems that words as carriers of meaning are not enough to show everything he wants and he also needs their sound component. Only with the fullness of meaning and sound his inspired reading performances arise. They have fascinated the audience and filled the theaters throughout Italy for years. For the complete artistic experience of written words Baricco needs, in some of the most elemental versions, the sound and dynamics of the read text, or, in a complex variant, music in combination with the text - text in music, text about music, text with music. The first and true Baricco`s love is classical music, however, curiosity and tendency toward experiments make him open to everything that is new, so he combines theater performance with elements of rave, jazz, or elements of radio forms. In this sense, Baricco can be classified as an actor. For if the abolition of the autonomy of Western arts with the aim of interdisciplinary connection is one of the basic features of performance (Stojnić 2015, 16), then certain forms of Baricco`s artistic practice can certainly be categorized, at least in that segment, under performance.

From the point of view of literature, his unconventionality, the constant need to destroy stereotypes, genre barriers and refuse to fit into any kind of matrix, classify Baricco as a postmodern writer. Consistent with this movement, he also has the need to constantly retell stories already told, ${ }^{15}$ from Homer over Cyrano de Bergerac to Melville. The themes Baricco writes and talks about are of a very wide spectrum, from Kate Moss to Proust, from Thucydides to Louis XVI, and they support the postmodernist stance that each story is worthy of testimony and that all divisions into large and small themes, high and popular culture are artificial.

Breaking the borders of terms and concepts, Baricco preserves deeply Appolinaire`s need to amaze and be amazed. Critics often complain that he does not do it the right way, but, regardless of the way seen in a different light, this need can be not only tolerable and legitimate, but with the appropriate aesthetic effect, even desirable for all those who consciously and deliberately agree to be seduced by a magic called art.

\section{REFERENCES}

Archivio. la Repubblica.it (1998). „Il Totem di baricco sfida la televisione“ https://ricerca.repubblica.it/ repubblica/archivio/repubblica/1998/12/19/il-totem-di-baricco-sfida-la-televisione.html, 12.12.2018.

Archivio. AdnAgenzia, (1995), „RAI3 'L'amore è un dardo” http://www1.adnkronos.com/Archivio/ AdnAgenzia/1995/07/22/Spettacolo/RAITRE-LAMORE-E-UN-DARDO_210900.php, 15.12.2018.

Baricco, A., (2008), Novecento, Feltrinelli,Milano.

Baricco, A., (2005), Omero, Iliade, Feltrinelli,Milano.

Baricco, A., (2013), Seta, Feltrinelli, Milano.

Bariko, A., Moizio, L., (2007), Španska partija (Partita spagnola-translation Ana Srbinović), Paideia, Beograd.

Baricco, A., Tarasco, R., Vacis, G., (2003), „Totem. L’ultima tournée“. http://www.oceanomare.com/news/ archivio/totemultima.htm, 23.10.2014.

Città di Vicenza, (2018), "POP Palladio Olimpico Projet, dal 20 aprile al via un nuovo modo di visitare il Teatro" https://www.comune.vicenza.it/albo/notizie.php/196246, 15.01.2019.

\footnotetext{
${ }^{15}$ Kibédi Varga states that it is precisely the tendency to retell already told stories - the "re-narration of the text", the basic feature of postmodern literature: "What may be the deepest characteristic of the new postmodern literature, that is, the re-narration of the text is the desire to talk again" (Kibédi Varga 1990, 16).
} 
di Bari, I., (2008), L’idea di letteratura in Alessandro Baricco: Il rapporto con la critica, la narrativa, l’esperienza cinematografica, Patti, Kimerik Edizioni.

Kibédi Varga, A., (1990), Le récit postmoderne.Littérature, 77, Didier, Paris: p. 10-21.

Larcan, L., (2007), "Baricco riscopre Moby Dick 'Ecco a voi il cuore del romanzo" in: La Repubblica, 20.11.2007. http://www.repubblica.it/2007/11/sezioni/spettacoli_e_cultura/bariccoauditorium/bariccoauditorium/baricco-auditorium.html, 21.03.2014.

Mentelocaletorino, (2017), "Alessandro Baricco e Francesco Bianconi: il reading di Furore - Spazio Mrf Mirafiori - Torino" https://www.mentelocale.it/torino/eventi/58418-alessandro-baricco-e-francescobianconi-il-reading-di-furore.htm, 15.12.2018.

Ottolina, P., (2003), "Racconto dell'Iliade", http://www.raccontodelllliad.it, 7.12.2012.

Ottolina, P., Carlini, F., (2000), "L`idea di Stephen Kong in Italia non funzionerebbe", in: Corriere della sera, 22.07.2000. http://archiviostorico.corriere.it/2000/luglio/22/idea_Stephen_King_Italia_non_co_0_000722162 .shtml, 26.11.2014.

Pivano, F., (2008), "Perchè Baricco" - recensione di Castelli di Rabbia, https://ilmestieredileggere.wordpress. com/2008/10/10/perche-baricco-recensione-di-castelli-di-rabbia-alessandro-baricco/, 23.01.2015.

Scippa, G., (2018), "Alessandro Baricco e Alessio Bertallot lanciano PLAYnovecento, la prima playlist di letteratura e musica" https://www.lifegate.it/persone/stile-di-vita/alessandro-baricco-e-alessio-bertallotplaynovecento, 15.01.2019.

Stojanovic Prelevic, I., (2018), Television and the aesthetic experience, in Facta universitatis, series Visual Arts and Music, vol 4, no. 2: pp. 81-87.

Stojnić, A., (2015), Teorija izvođenja u digitalnoj umetnosti (Theory of Performing in Digital Art), Beograd: Fakultet za medije i komunikacije i Orion art.

\section{UMETNIČKI IZAZOVI ALESANDRA BARIKA - KNJIŽEVNOST I MUZIKA}

Tema rada su multidisciplinarne aktivnosti italijanskog pisca Alesandra Barika koje u sebi sadrže elemente književnosti i muzike. Bariko je muzički kritičar i tvorac televizijskog serijala koji se bavi popularizacijom opere, ali i mnogih hibridnih umetničkih formi koje sjedinjuju književnost $i$ muziku: specifičnih pozorišnih izvođenja - Totema, javnih čitanja, rejv čitanja, književnih plejlisti. $U$ navedenim aktivnostima prepoznatljiva je piščeva postmoderna orijentacija i sklonost $k a$ performansu. Rad ukazuje i na čestu neusaglašenost kritike i publike kada je reč o recepciji njegovih dela, kao i na polarizaciju unutar redova samih kritičara.

Ključne reči: književnost, muzika, čitanje, opera, pozorište. 